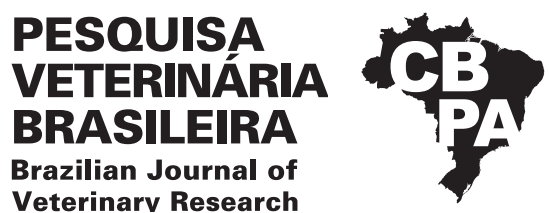

Pesq. Vet. Bras. 40(8):571-578, August 2020 DOI: 10.1590/1678-5150-PVB-6657

Review Article

Livestock Diseases

ISSN 0100-736X (Print)

ISSN 1678-5150 (Online)

(cc) BY-NC

\title{
Causes of death in feedlot beef cattle and their control: a brief review ${ }^{1}$
}

\author{
Pablo Estima-Silva ${ }^{2}$, Haide Valeska Scheid ${ }^{2}$ (D) and Ana Lucia Schild ${ }^{3 *}$ (D)
}

\begin{abstract}
Estima-Silva P., Scheid H.V. \& Schild A.L. 2020. Causes of death in feedlot beef cattle and their control: a brief review. Pesquisa Veterinária Brasileira 40(8):571-578. Laboratório Regional de Diagnóstico, Faculdade de Veterinária, Universidade Federal de Pelotas, Campus Universitário, Pelotas, RS 96010-900, Brazil. E-mail: alschild@terra.com.br

This review reports the leading causes of death in feedlot beef cattle. It describes economic losses resulting from these deaths and suggests control alternatives. Diseases associated with the respiratory and digestive systems were the most frequently observed. In different geographical areas, the importance of each one might vary. Outbreaks of diseases such as botulism occur occasionally and can cause important economic losses. Cattle tick fever can cause significant losses in zones of enzootic tick instability. Technical assistance and sanitary and food management are critical for the best productivity in feedlot cattle.
\end{abstract}

INDEX TERMS: Feedlot, cattle, morbidity, mortality, pneumonia, acidosis, bloat.

\begin{abstract}
RESUMO.- [Causas de morte em bovinos de corte confinados e seu controle: uma breve revisão.] Esta revisão discute as principais causas de morte em bovinos de corte em confinamento. Descreve as perdas econômicas resultantes dessas mortes e sugere alternativas de controle. As doenças associadas aos sistemas respiratório e digestivo foram as mais frequentemente observadas. Em diferentes áreas geográficas, a importância de cada uma pode variar. Surtos de doenças como o botulismo ocorrem ocasionalmente e podem causar importantes perdas econômicas. A tristeza parasitária bovina pode causar perdas significativas em zonas de instabilidade enzoótica do carrapato. A assistência técnica e um bom gerenciamento sanitário e alimentar são essenciais para a melhor produtividade em bovinos de corte confinados.
\end{abstract}

TERMOS DE INDEXAÇÃO: Confinamento, bovinos, morbidade, mortalidade, pneumonia, acidose, timpanismo.

\section{INTRODUCTION}

A feedlot is a system for raising a significant number of cattle with high-cost control in restricted areas, feeding them with commercial rations or rations produced in the premises

\footnotetext{
${ }^{1}$ Received on April 2, 2020.

Accepted for publication on April 16, 2020.

${ }^{2}$ Graduate Program in Veterinary, Faculdade de Veterinária (FV), Universidade Federal de Pelotas (UFPel), Campus Capão do Leão, Capão do Leão, RS 96010-900, Brazil.

${ }^{3}$ Laboratório Regional de Diagnóstico, Faculdade de Veterinária (FV), Universidade Federal de Pelotas (UFPel), Campus Capão do Leão, Capão do Leão, RS 96010-900, Brazil. *Corresponding author: alschild@terra.com.br
}

(Barbieri et al. 2016). The main objective of the feedlot is to obtain finished cattle for slaughter throughout the year, including those periods of forage scarcity, and depending to a minimum on pastures and favorable climatic conditions. Besides, feedlots are used for stock and quarantine beef cattle before the export of livestock (Bailone 2019), and for raise and hold breeding bulls (Malafaia et al. 2016).

The first feedlot on record dates from 1876 in the United States, when a large number of cattle were fed simultaneously on grain in a crop farm close to slaughterhouses. Thee feedlot practice was then an alternative to extensive livestock farming, which would be too distant from slaughterhouses and, thus, too expensive (Hubbs 2010). Subsequently, in the 1950s and 1960s, feedlots emerged as a result of new technologies and improved grain production with more productive crops (Hubbs 2010). Currently, most of the finishing of cattle for slaughter in the United States occurs in feedlots (Edwards 2010) since farmers raise more than $75 \%$ of calves for meat production in this system (Grandin 2016). In Australia, the feedlot industry started in the 1960s and has kept on expanding until today, having increased from 750,000 feedlots (comprising 3.4\% of the country's total cattle herd) in the 1990 s to 2.8 million $(12 \%)$ in 2015 (Mayberry et al. 2019).

In Brazil, the first known beef cattle feedlot to exist was created in 1961 in the city of Ourinhos, state of São Paulo, as an alternative for finishing cattle during the dry season (USP-ESALQ 2019). Since the 1970s, there has been an exponential increase in the Brazilian bovine population. In the same period, there was also an expansion of agricultural areas facilitated by new technologies that allowed plowing and sowing of large plots of land in a short period. This took 
over extensive areas for crops leaving increasingly lesser space for livestock. The search for an alternative resulted win a steep increase in the number of cattle raised in the feedlot system (Rezende 2010), and since 1980, feedlots became a real alternative to cattle raising (Malafaia et al. 2016). In $2018,12.6 \%$ of the 44.23 million cattle officially slaughtered across the country were finished at feedlots (ABIEC 2019).

Traditionally, in the State of Rio Grande do Sul (RS), in the southern region of Brazil, cattle ranching has always been associated with large extensions of land. Cattle were raised grazing on native or cultivated pastures or rice or soybean crop leftovers. However, in recent years, the number of feedlots with different purposes has increased in the region (Estima-Silva et al. 2020).

With the advancement of feedlot systems in the world, cattle diseases became an increasing concern for producers and veterinarians. A review (Kelly \& Janzen 1986) on diseases of feedlot cattle has shown that cattle morbidity in these systems can reach 69\%, ranging from 15-45\%. Regarding mortality, the rate reached up to $15 \%$, with most reports mentioning 1-5\% mortality. The same authors observed that the peak of disease occurred in the first three weeks of admission to the feedlots, and the leading conditions were those affecting the respiratory system (Kelly \& Janzen 1986). In Brazil, in a feedlot in the Southeast region, morbidity rates of $7.05 \%$ and mortality of $0.64 \%$ have been reported (Baptista et al. 2017). In Minas Gerais, the morbidity of $7.76 \%$ and mortality of $1.5 \%$ were observed (Martins 2016). In the southern region of RS, mortality rates of $0.11 \%$ and $1.33 \%$ were found in feedlots for the export of live animals and for finishing cattle, respectively (Estima-Silva et al. 2020).

This paper aimed to review the leading causes of death of feedlot beef cattle. It was also our intention to demonstrate the economic impact that they cause in the livestock industry and how to assist veterinary practitioners and farmers, offering solutions to reduce financial losses in their farming systems.

\section{POTENTIAL CAUSES OF MORTALITY IN FEEDLOT BEEF CATTLE}

Feedlot cattle are more susceptible to infections respiratory diseases such as pneumonia and non-communicable diseases of the alimentary tract such as lactic acidosis and bloat (Smith 1998, Borges \& Afonso 2007). There are reports of occasional outbreaks of other conditions affecting cattle in feedlots with significant losses, such as botulism in Rio Grande do Sul (Maboni et al. 2010) and the Midwest (Soares et al. 2018, Guizelini et al. 2019) regions and tick fever in RS (Estima-Silva et al. 2020).

\section{Pneumonias}

Respiratory diseases (Fig.1) are the leading morbid conditions in feedlot cattle in the United States (Sanderson et al. 2008, Edwards 2010, Wilson et al. 2017), Australia (Cusack 2004), Canada (Church \& Radostits 1981, Smith 1998), and Brazil (Malafaia et al. 2016, Baptista et al. 2017). These diseases impact the meat industry, with direct losses due to deaths, treatment, and human resources and indirect losses associated with low animal development, increased permanence of cattle in the feedlot, and lower carcass yield (Smith 1998, Wilson et al. 2017). Despite advances in management and new treatment protocols and vaccines, the cumulative incidence of bovine respiratory disease (BRD) in feedlot cattle has not decreased over the past 30-40 years (Edwards 2010).

The causes of BRD are complex and associated with several viruses, namely bovine respiratory syncytial virus (BRSV), bovine herpesvirus-1 (IBR), bovine viral diarrhea virus (BVDV) and parainfluenza virus type 3 (PIV-3). Such viruses establish a favorable environment for the colonization and replication of pathogenic bacteria such as Pasteurella multocida, Mannheimia haemolytica, Streptococcus pneumoniae, Mycoplasma bovis, and Histophilus somni, resulting in pneumonia (Urban-Chmiel \& Grooms 2012). These diseases represent $45 \%$ of the causes of death in feedlot cattle in the United States (Edwards 2010, Cernicchiaro et a.l. 2012, Avra et al. 2017) and approximately $75 \%$ of the total morbidity (Edwards 2010). In Australia, the mortality rate reaches $50 \%$ (Hay et al. 2016). In one study the Midwest region of Brazil (Malafaia et al. 2016), 45\% of the diagnoses of diseases in feedlot cattle were BRD, and in one feedlot in the Southeast (Baptista et al. 2017), 87\% of the total diagnoses were pneumonia and mortality from this disease was $20 \%$. In the Southern region of RS, over 20 years, BRD represented $11 \%$ of all illnesses that causing death in cattle from several different feedlot systems (Estima-Silva et al. 2020).

The economic impact of pneumonia on feedlot cattle. Costs associated with respiratory diseases in feedlot beef cattle in the United States is estimated at 4 billion dollars a year, including, in addition to deaths, costs of treatment, prevention, and loss of productivity (Cernicchiaro et al. 2012). In the USA, in a study on treatment failure of these diseases (Avra et al. 2017), the authors describe an increase of approximately $85 \%$ in treatment costs over 12 years, that is, it was US \$ 12.59 per bovine in 1999 and \$ US 23.60 in 2011. In a study carried out in Brazil (Malafaia et al. 2016), the economic impact with treatment for BRD was, on average, \$ US 21.70 per cattle with losses on average of $13.4 \mathrm{~kg}$ body weight per animal. In another study in cattle feedlots in the Southeast region of Brazil (Baptista et al. 2017), treatment

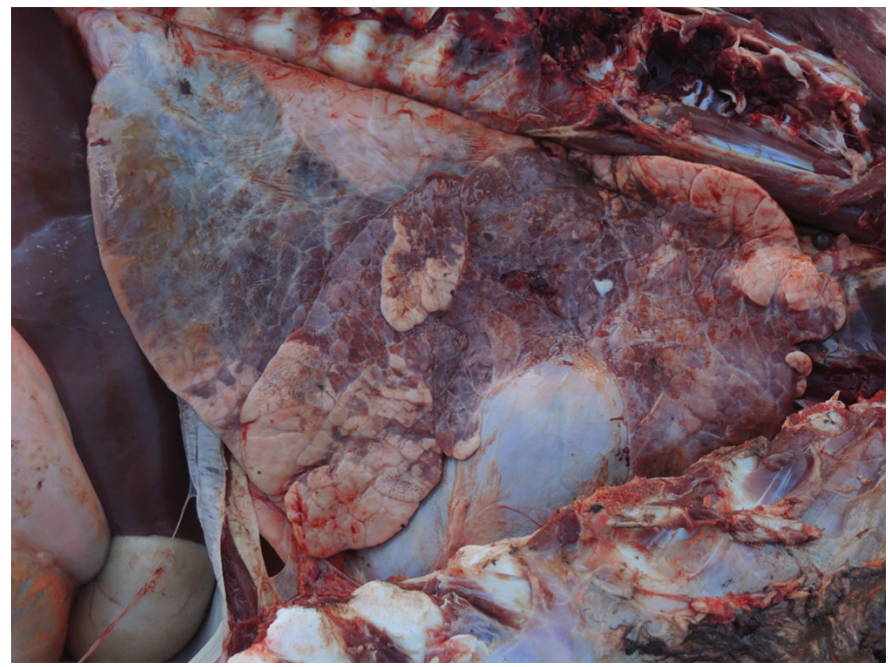

Fig.1. Thorax cavity from a feedlot steer that died from pneumonia. There are dark areas of consolidation affecting all pulmonary lobes. Adjacent areas show checkers pattern with intercalated dark and pale areas. 
costs were US $\$ 26.62$ per animal and losses due to mortality were US \$ 682.40 per animal; the calculation included the treatment, and the human resources cost added to the value of the animal. The relevance of respiratory diseases and their economic impact on the management of feedlot cattle has led to the development of programs seeking to minimize the costs in these types of cattle raising systems (Edwards 2010).

Control alternatives for pneumonia in feedlot cattle. The first 45 days of arrival at the feedlot are critical to the occurrence of BRD since this is a period of stress caused by weaning, the shipment of cattle to the feedlot, nutritional changes, and handling of animals shortly after arrival (Smith 1998, Edwards 2010). To reduce the losses, the administration of antibiotics to cattle on arrival at feedlots (metaphylaxis) have been advised, regardless of whether these animals show any clinical signs of illness (Catry et al. 2008, Edwards 2010, Nickell \& White 2010, Rezende 2010). This way of preventing pneumonia in feedlot cattle is deemed efficient considering the drop in rates of morbidity and mortality due to BRD and the increase in weight gain of treated animals, which makes the practice economically viable (Catry et al. 2008, Edwards 2010, Nickell \& White 2010, Rezende 2010). The use of a metaphylaxis program shortly after the arrival of cattle to the feedlot reduced the occurrence of BRD by $50 \%$ and the mortality from this disease by $25 \%$ (Urban-Chmiel \& Grooms 2012). Rezende (2010), in an experiment performed in feedlots in the Midwest region of Brazil, observed that a single application of florfenicol to a group of cattle at their entrance to the feedlot was effective in reducing BRD morbidity by $54 \%$. Also, an increase in weight gain occurred, indicating this treatment as economically viable when BRD morbidity rates are higher than $2.7 \%$. However, the use of antibiotics is not free of secondary problems. Antibiotic residues in the meat and inducement of resistance to the active ingredient are threats that linger on (Moreno \& Lanusse 2017).

Vaccines can be used to minimize the occurrence of BRD in feedlot cattle. Currently, vaccines against the different viral and bacterial agents involved in BRD are widely available in Brazil. Proper use of these vaccines reduces the risk of disease (Urban-Chmiel \& Grooms 2012). In a study on BRD mortality in feedlot cattle, those who were not vaccinated were 11.95 times more likely to die from BRD than those who were (Estima-Silva et al. 2020). Mortality was significantly higher in non-vaccinated finishing feedlot cattle in comparison to in younger, more susceptible animals vaccinated at arrival at the feedlot (Estima-Silva et al. 2020). However, the stress experienced by cattle during the first days at the feedlot can compromise the efficiency of the immune response to the vaccine (Edwards 2010, Urban-Chmiel \& Grooms 2012). Two vaccinations performed 60 and 30 days before the entrance to the feedlot is more efficient than a single dose vaccination on arrival at the feedlot. In the latter case, cattle were 2.5 times more likely to die from BRD than those of animals on the arrival at the feedlot or 14 days after the entry did not significantly influence the occurrence of the disease (Richeson et al. 2008). In general, vaccine protocols show controversial results concerning BRD morbidity and mortality in confined cattle (Edwards 2010).

The increase in the efficiency of the BRD vaccine has been evident when it is performed during pre-conditioning programs. This pre-conditioning consists in performing surgical procedures, such as dehorning and castration, treating the animals with anthelmintics, and adapting them to feed in troughs and drinking fountains approximately 30 45 days before entering the feedlot. This is a strategy used in the United States that aims to reduce the stress of cattle due to the sudden change of feed and surgical procedures necessary on arrival at the feedlot. These animals have greater sale values, but, at the end, they are more profitable since the morbidity and mortality due to BRD and other diseases decrease (Urban-Chmiel \& Groons 2012).

BRD is a multifactorial disease complex of great importance in feedlot systems in general. Several viral and bacterial agents are involved in the pathogenesis of BRD. Consequently, BRD requires the use of different strategies for its proper control and reduction of economic losses. Several studies report the optimal time for vaccination or the use of metaphylaxis, or even adopting pre-conditioning programs that can make a difference in the morbidity and mortality rates for BRD. This pre-conditioning can also be significant for animal welfare, since the cattle to a new feeding system in the period before confinement, can avoid the stress produced by all these practices on arrival at the feedlot (Mota \& Marçal 2019).

\section{Digestive tract disorders}

Acidosis is one of the most common gastrointestinal disorders of feedlot cattle since grain feeding became a widespread practice (Nagaraja \& Lechtenberg 2007, Snyder \& Credille 2017). In Brazilian feedlot cattle, ruminal acidosis is second only to pneumonia as the leading cause of morbidity and mortality (Malafaia et al. 2016). In one study, done in feedlot cattle for finishing or export, acidosis was the leading cause of death, surpassing pneumonia (Estima-Silva et al. 2020).

Ruminal acidosis results from the consumption of high amounts of rapidly fermentable carbohydrates $(\mathrm{CH})$. (Galyean \& Rivera 2003, Nagaraja \& Lechtenberg 2007). Ruminal bacteria respond to the increased availability of fermentable substrates by increasing growth rates and fermentative activities, that is, the introduction of this highly fermentable $\mathrm{CH}$ in the diet leads to a reduction in fibrolytic bacteria, the rapid growth of amylolytic bacteria and a decrease in ruminal $\mathrm{pH}$ (Bevans et al. 2005). Although many ruminal bacteria can use starch, the explosive growth of Streptococcus bovis, in response to the availability of fermentable $\mathrm{CH}$, is observed only in situations where the ruminant is not adapted to the grain or during the period of intensification of feeding (Nagaraja \& Lechtenberg 2007). Acute acidosis (Fig.2), which causes mortality, is due to excessive $\mathrm{CH}$ intake when animals are not adapted to such a diet, when there is a change of diet after fasting or when an already adapted bovine abruptly ingests high amounts of highly fermentable carbohydrate (Borges \& Afonso 2007). In acute acidosis lactate and volatile fatty acids accumulate, resulting in an increased osmotically ruminal content. Lactate also causes damage to the epithelial lining of ruminal mucosa. Those changes together lead to extensive extravasation of liquid into the rumen resulting in marked dehydration that may be fatal (Owens et al. 1988). Ruminal acidosis can, therefore, be defined as a ruminal fermentation disorder characterized by below the normal ruminal $\mathrm{pH}$, reflecting an imbalance between microbial production, microbial utilization, and ruminal absorption of volatile fatty acids (Hernández et al. 2014). 
Another frequent digestive disorder in intensively bred cattle is frothy bloat (Fig.3) resulting from the fermentation of grain feed, with excessive production of gases, mainly carbon dioxide and methane that mix with the rumen content forming the foam (Meyer \& Bryant 2017, Abdisa 2018). Physiologically, these gases are produced by the action of bacteria and rumen protozoa on fermentable foods. The gases are expelled by absorption through the rumen wall, passing to the next stomach compartment or by eructation through the esophagus, which is the main route of expulsion (Meyer \& Bryant 2017, Abdisa 2018). The foam pathologically accumulated in bloat is due to a bacterial mucopolysaccharide that originates in the bacterial wall or in its cytoplasm. The increased production of this mucopolysaccharide, due to the increase in ruminal bacteria, turns the ruminal fluid thick and viscous, making it difficult to separate it from the gas in the rumen content resulting in foam (Borges \& Afonso 2007).

Reports on morbidity and mortality rates of digestive disorders in feedlots cattle are variable. In the USA, it is estimated that approximately $4.4 \%$ of feedlot cattle are diagnosed with digestive disorders (USDA 2011). The same report states that $14-42 \%$ of deaths in feedlot cattle are due to these problems, making digestive disorders (Smith 1998, Nagaraja \& Lechtenberg 2007, Snyder \& Credille 2017), which would make these disorders the second most important cause of mortality in feedlot cattle. Others report mortality rates from digestive disorders as $19.5 \%-28.4 \%$ of all diseases diagnosed in American feedlot cattle (Meyer \& Bryant 2017). These latter authors found $96.3 \%$ of cases of bloat and $3.7 \%$ of cases of ruminal acidosis.

In Brazil, rates of 31\%-32.7\% were found among all observed diseases in feedlot finishing cattle and breeding bulls (Malafaia et al. 2016). In the South of Rio Grande do Sul, digestive diseases represented $57.3 \%$ among all diseases that caused the death of cattle in different feedlot systems over 20 years. Of those deaths, $52.2 \%$ resulted from acidosis and 45.8\% from bloat (Estima-Silva et al. 2020).

Control alternatives to digestive disorders. The acute course of digestive disorders is challenging to timely diagnosis and treatment (Meyer \& Bryant 2017). Ruminal acidosis and

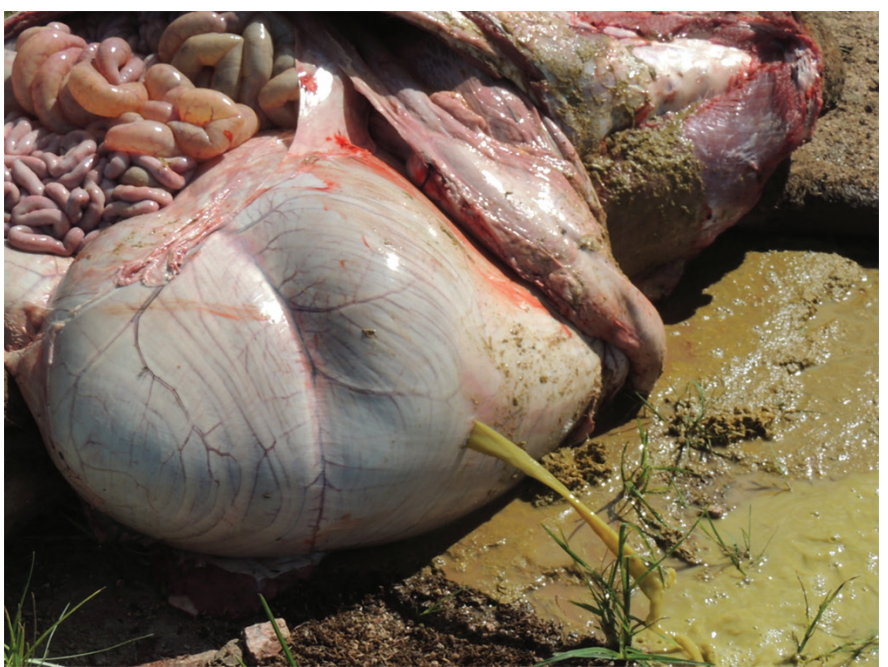

Fig.2. Rumen from a feedlot steer that died from acute ruminal lactic acidosis. The ruminal content is abundant, liquid, and yellow-green. bloat are complex and overlapping disorders, which makes it virtually impossible to establish a single management practice in their control (Cheng et al. 1998, Meyer \& Bryant 2017). The control of acidosis clearly depends on proper nutritional management and adaptation of animals to a high CH diet; the disorder can, however, occur even when cattle are gradually adapted to a grain diet (Bevans et al. 2005). The adaptation consists of decreasing the concentration of roughage and gradually increasing the concentrate in the diet. To carry out the adjustment, the history of the animals, whenever available, should be considered. Cattle previously raised on pasture with no exposure to concentrated feed are more susceptible to changes in ruminal $\mathrm{pH}$ and, therefore, more vulnerable to acidosis and bloat. Adaptation to the concentrate should last a minimum of 3-4 weeks; s cattle adapted for shorter periods remain more susceptible to digestive disorders (Nagaraja \& Lechtenberg 2007, Hernández et al. 2014, Meyer \& Bryant 2017).

Basically, the percentage of fiber in the feed at the beginning of the adaptation is $45 \%$ to $55 \%$ (Meyer \& Bryant 2017). Studies have shown that the provision of highly concentrated diets ad libitum during the first weeks of adaptation results in a drastic reduction in food intake (Schwartzkopf-Genswein et al. 2003, Brown et al. 2006, Meyer \& Bryant 2017). A comparative study between rapid versus gradual adaptation of feedlot heifers to a diet that increased from $40 \%$ to $90 \%$ in concentrate is reported (Bevans et al. 2005). In both types of adaptation, concentration went from $40 \%$ to $905 \%$ of dry matter. In fast adaptation, the percentage of concentrate went from 40 to $90 \%$ in 3 days with an intermediate phase of $65 \%$ of concentrate for three days. In the gradual transition, the concentrate levels increased by $48.3 \%, 56.7 \%, 65.0 \%, 73.3 \%$, and $81.7 \%$ every five days until reaching $90 \%$. The authors concluded that the majority of heifers were able to adapt quickly, requiring few steps of gradual increase in the diet. However, ideal adaptation should favor those most vulnerable individuals to prevent outbreaks.

The association of concentrate with roughage is therefore essential to avoid morbidity from digestive diseases in feedlot cattle since fiber is necessary to stimulate ruminal movements and promote saliva production. Roughage dietetic levels

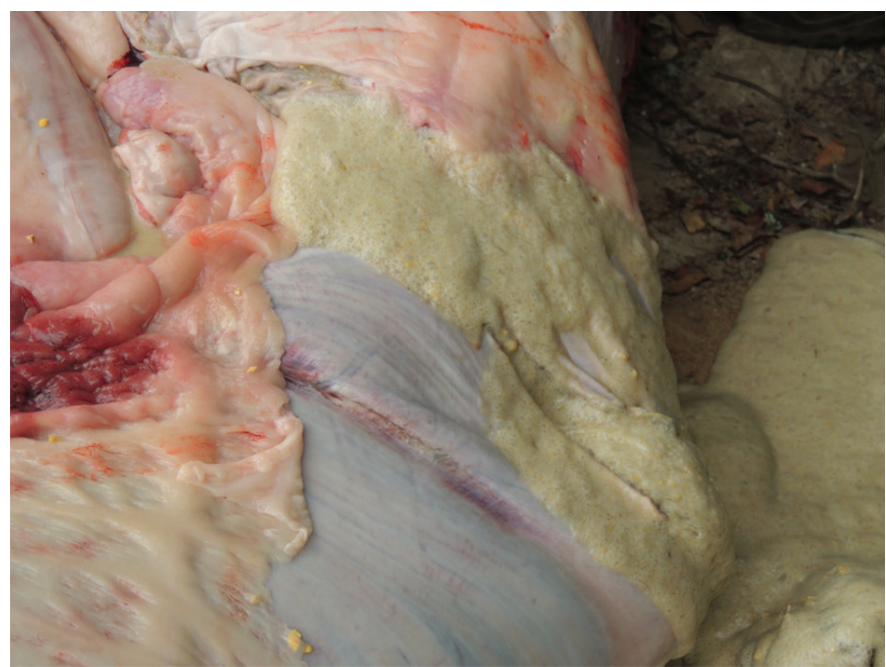

Fig.3. Rumen from a feedlot steer that died from frothy bloat resulting from grain overload. Ruminal content is yellow and frothy. 
decreased over the past few years due to the difficulty in storage, handling, and mixing with the concentrate. Currently, roughage corresponds to a maximum of $8 \%$ of dry matter, less than that $10 \%-15 \%$ used 20 years ago (Nagaraja \& Lechtenberg
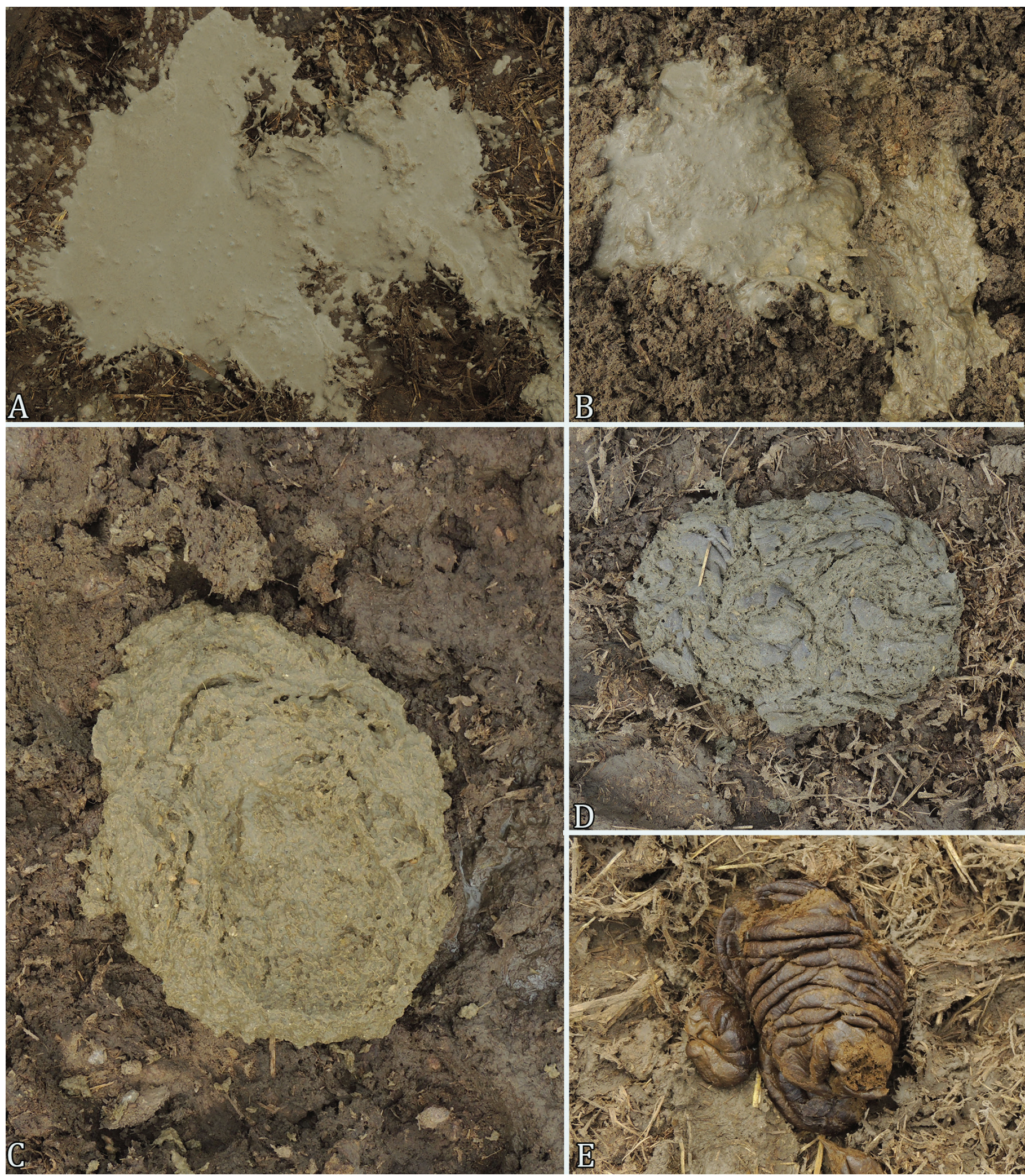

Fig.4. Stool score indicating the balance between concentrate and roughage in the diet of feedlot cattle. The score ranges from 1 (excess protein or starch) to 5 (poor digestion of forage. Score 3 represents the balance in the composition of the diet (Adapted from Vigne et al. 2019). (A) Score 1: liquid stools; diarrheic. (B) Score 2: semi-liquid stools. (C) Score 3: pasty stools. (D) Score 4: Light and moderately dry stools, with concentric rings and 3-4cm layers. (E) Score 5: dry and hard stools. 
2007). In many cases, despite the use of roughage associated with the concentrate, digestive disorders are still a significant cause of death in feedlots operations in RS (Estima-Silva et al. 2020).in feedlots operations in RS (Estima-Silva et al. 2020).

The strategy to decrease the morbidity rates of bloat in feedlot operations includes, besides the association of concentrate with roughage, the choice of the cereal to be fed. Wheat has a higher fermentation rate than corn, sorghum, and barley; thus, bloat tends to be more frequent in feedlot cattle fed wheat-based diets (Cheng et al. 1998).

The processing of cereal entering the diet of feedlot cattle also plays a part in the occurrence of both acidosis and bloat. The more finely ground the starch, the more facilitate its digestion by microbial enzymes, leading o accelerated production of organic acids and mucopolysaccharides, consequently lowering the $\mathrm{pH}$ and increased viscosity of rumen content (Cheng et al. 1998, Meyer \& Bryant 2017).

There is a parameter called "stool score", which consists of evaluating the stool on a scale of 1-5. Score 1 represents diarrheic stools indicating excess protein or starch; score 5 indicates dry stools denoting inadequate digestion of forage by ruminal microrganisms and scarcity of degradable protein in the diet (Fig.4). This parameter aids in assessing the balance of concentrate and roughage administered to cattle maintaining the weight gain and minimizing the occurrence of digestive disorders. The ideal score is 3 (Schwartzkopf-Genswein et al. 2003, Ferreira et al. 2013, Meyer \& Bryant 2017).

Trough management asseses the consumption of an ideal amount of the diet administered to animals (SchwartzkopfGenswein et al. 2003, Meyer \& Bryant 2017). This practice takes it account the daily leftover of feed in the troughs daily, observed at the same period of the day, namely Feedbunk Scoring System (Table 1). Scores correspond to 0, for a clean trough and 4 for an intact trough. Score 1 denotes the ideal diet that will avoid acidosis and maintain weight gain (Meyer \& Bryant 2017).

Another popular practice of controlling digestive disorders in feedlot cattle is the use of food additives such as ionophores, mainly monensin. Those substances will affect lactic acid-producing gram-negative bacteria are effective in controlling acute acidosis and promoting significant food efficiency (Meyer \& Bryant 2017). Ionophores also prevent the occurrence of bloat. Cases of bloat in feedlot cattle were decreased by $64 \%$ and $92 \%$ respectively by monensin and lasalocid (Bartley et al. 1983).

Other additives have been suggested to prevent digestive diseases in feedlot cattle, such as baking soda, mineral oil, and

\section{Table 1. Feedbunk scoring system}

\begin{tabular}{cl}
\hline Score & Description \\
\hline 0 & No feed remaining in bunk \\
0.5 & $\begin{array}{l}\text { Scattered feed remaining. Most of the bottom of the bunk } \\
\text { exposed }\end{array}$ \\
1 & $\begin{array}{l}\text { Thin, uniform layer of feed remaining. About one corn kernel } \\
\text { deep }\end{array}$ \\
2 & $\begin{array}{l}25 \text { to } 50 \% \text { of feed remaining } \\
\text { More than } 50 \% \text { of feed remaining. Crown is thoroughly } \\
\text { disturbed }\end{array}$ \\
& Feed is virtually untouched. Crown of feed still noticeable
\end{tabular}

Source: Pritchard R.H. (1993). probiotics whose, but their results are controversial (Meyer \& Bryant 2017). Some authors, however, consider these additives to be good tools to control the digestive diseases of feedlot cattle (Hernández et al. 2014, Valente et al. 2017).

Other precautions are suggested to prevent digestive diseases that cause death in feedlot cattle. Weight of livestock entering the feedlot should be uniform as possible to avoid the dominance of larger animals and monitoring animals to observe behavior and early clinical signs that might suggest bloat. When more than 3\% of the animals in the flock have ruminal distension, action must be taken immediately to prevent an outbreak of bloat (Hernández et al. 2014).

\section{Other diseases that cause mortality in feedlot cattle}

In feedlot beef cattle, conditions such as botulism (Maboni et al. 2010, Soares et al. 2018, Guizelini et al. 2019, Le Maréchal et al. 2019) occasionally cause economic losses in feedlot beef cattle operations. The study of an outbreak of botulism in the Midwest region with morbidity and mortality of $0.4 \%$ and a financial loss of more than US $\$ 13,000.00$ is described (Curci et al. 2013). In another outbreak in the same region (Guizelini et al. 2019), a total of 1090 out of 1700 feedlot steers died due to the ingestion of corn silage contaminated with Clostridium botulinum neurotoxin type C (Fig.5). Vaccine can be effective. Still, vaccinating cattle after the outbreak started, it is not the best practice (Curci et al. 2013).

The elimination of the source of contamination of the botulinic toxin is an adequate measure (Soares et al. 2018). The storage and periodic cleaning of the food and water storage place and troughs minimize the risks of botulism outbreaks and are also part of animal welfare (Mota \& Marçal 2019).

Bovine tick fever is observed mainly in feedlot cattle, the southern region of Rio Grande do Sul with mortality of up to $2.5 \%$ (Estima-Silva et al. 2020). The disease is especially important in areas of enzootic instability for the tick that results in outbreaks with considerable losses (Farias 2007). Although the feedlot environment is not ideal for the vector,

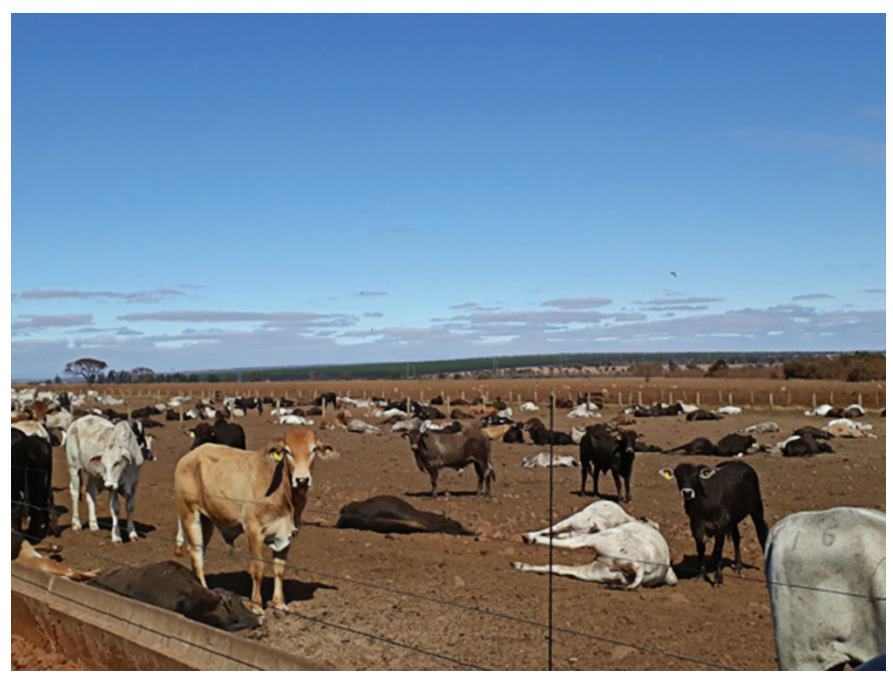

Fig.5. Botulism. Several feedlot steers are affected in a massive outbreak in Mato Grosso do Sul. A total of 1090 out of 1700 feedlot steers died due to the ingestion of corn silage contaminated with Clostridium botulinum neurotoxin type C (Courtesy of Dr. Tessie Möck, Ulmer Straße 1489180 Berghülen, Germany). 
many cattle arrive as during the incubation period of the disease (Estima-Silva et al. 2020). In these cases, chemoprophylaxis with anaplasmicidal and babesicidal drugs should be considered, which, in addition to demonstrating efficiency in controlling the disease (Estima-Silva et al. 2020), increase the weight gain of confined cattle (Silva et al. 2015).

\section{CONCLUSIONS}

The primary diseases affecting feedlot cattle are those associated with the respiratory and the digestive systems.

Technical assistance and proper sanitary and food management are critical in raising cattle in confinement for meat production, the export of live animals, or breeding.

Also, practitioners should consider endemic diseases in each region when facing mortality outbreaks in feedlots.

Acknowledgments.- This study was financed in part by the "Coordenação de Aperfeiçoamento de Pessoal de Nível Superior” (CAPES), Brazil, Finance Code 001.

Conflict of interest statement.- There are no conflicts of interest.

\section{REFERENCES}

Abdisa T. 2018. Study on the prevalence of bovine frothy bloat in and Around Kebele Lencha, Tokke Kutaye District, Oromia Region. Appro. Poult. Dairy Vet. Sci. 2(3):1-10. <https://dx.doi.org/10.31031/APDV.2018.02.000537>

ABIEC 2019. Perfil da pecuária no Brasil. Beef report, Associação Brasileira das indústrias Exportadoras de Carnes Bovinas. 49p.

Avra T.D., Abell K.M., Shane D.D., Theurer M.E., Larson R.L. \& White B.J. 2017. A retrospective analysis of risk factors associated with bovine respiratory disease treatment failure in feedlot cattle. J. Anim. Sci. 95(4):1521-1527. <https://dx.doi.org/10.2527/jas.2016.1254><PMid:28464093>

Bailone R.L. 2019. Exportação de animais vivos e o bem-estar animal do Brasil: um panorama da situação atual. Revta Educ. Contin. Med. Vet. Zootec. CRMV-SP 17(1):34-38. <https://dx.doi.org/10.36440/recmvz. v17i1.37841>

Baptista A.L., Rezende A.L., Fonseca P.A., Massi R.P., Nogueira G.M., Magalhães L.Q., Headley S.A., Menezes G.L., Alfieri A.A. \& Saut J.P.E. 2017. Bovine respiratory disease complex associated mortality and morbidity rates in feedlot cattle from southeastern Brazil. J. Infect. Dev. Ctries. 11(10):791799. <https://dx.doi.org/10.3855/jidc.9296><PMid:31600152>

Barbieri R.S., Carvalho J.B. \& Sabbag O.J. 2016. Análise de viabilidade econômica de um confinamento de bovinos de corte. Interações, Campo Grande, 17(3):357-369. <https://dx.doi.org/10.20435/1984-042X-2016v.17-n.3(01)>

Bartley E.E., Nagaraja T.G., Pressman E.S., Dayton A.D., Katz M.P. \& Fina L.R. 1983. Effects of lasalocid or monensin on legume or grain (feedlot) bloat. J. Anim. Sci. 56(6):1400-1406. <https://dx.doi.org/10.2527/ jas1983.5661400x > <PMid:6874619>

Bevans D.W., Beauchemin K.A., Schwartzkopf-Genswein K.S., McKinnon J.J. \& McAllister T.A. 2005. Effect of rapid or gradual grain adaptation on subacute acidosis and feed intake by feedlot cattle. J. Anim. Sci. 83(5):1116-1132. <https://dx.doi.org/10.2527/2005.8351116x> <PMid:15827257>

Borges J.R.J. \& Afonso J.A.B. 2007. Doenças não transmissíveis do trato digestivo de ruminantes, p.295-380. In: Riet-Correa F., Schild A.L., Lemos R.A.A. \& Borges J.R.J. (Eds), Doenças de Ruminantes e Equídeos. Vol.2. 3rd ed. Pallotti, Santa Maria.

Brown M.S., Ponce C.H. \& Pulikanti R. 2006. Adaptation of beef cattle to high-concentrate diets: performance and ruminal metabolism. J. Anim. Sci. 84(supl.):E25-E33. <https://dx.doi.org/10.2527/2006.8413_supple25x> $<$ PMid:16582090>
Catry B., Duchateau L., Van de Ven J., Laevens H., Opsomer G., Haesebrouck F. \& de Kruif A. 2008. Efficacy of metaphylactic florfenicol therapy during natural outbreaks of bovine respiratory disease. J. Vet. Pharmacol. Ther. 31(5):479-487. <https://dx.doi.org/10.1111/j.1365-2885.2008.00981.x> $<$ PMid:19000268>

Cernicchiaro N., Renter D.G., White B.J., Babcock A.H. \& Fox J.T. 2012. Associations between weather conditions during the first 45 days after feedlot arrival and daily respiratory disease risks in autumn-placed feeder cattle in the United States. J. Anim. Sci. 90(4):1328-1337.<https://dx.doi org/10.2527/jas.2011-4657><PMid:22147486>

Cheng K.J., McAllister T.A., Popp J.D., Hristov A.N., Mir Z. \& Shin H.T. 1998. A review of bloat in feedlot cattle. J. Anim. Sci. 76(1):299-308 <https://dx.doi.org/10.2527/1998.761299x><PMid:9464911>

Church T.L. \& Radostits O.M. 1981. A retrospective survey of diseases of feedlot cattle in Alberta. Can. Vet. J. 22(2):27-30. <PMid:7225993>

Curci V.C.M., Zocoller-Seno M.C., Nogueira A.H.C, Araujo R.F., Cardoso T.C \& Dutra I.S. 2013. Resposta humoral de bovinos vacinados contra as toxinas botulínicas tipos C e D em diferentes faixas etárias. Arqs Inst. Biológico, São Paulo, 80(1):99-102. <https://dx.doi.org/10.1590/S180816572013000100014>

Cusack P.M.V. 2004. Effect of mass medication with antibiotics at feedlot entry on the health and growth rate of cattle destined for the Australian domestic market. Aust. Vet. J. 82(3):154-156. <https://dx.doi. org/10.1111/j.1751-0813.2004.tb12644.x><PMid:15088981>

Edwards T.A. 2010. Control methods for bovine respiratory disease for feedlot cattle. Vet. Clin. N. Am., Food Anim. Pract. 26(2):273-284. <https://dx.doi. org/10.1016/j.cvfa.2010.03.005><PMid:20619184>

Estima-Silva P., Oliveira P.A., Bruhn F.R.P., Scheid H.V., Marques L.S., Ribeiro L.S. \& Schild A.L. 2020. Causes of death of beef cattle raised in feedlots in Southern Brazil. Pesq. Vet. Bras. 40(5):333-339. <https://dx.doi. org/10.1590/1678-5150-pvb-6539>

Farias N.M. 2007. Tristeza parasitária, p.524-532. In: Riet-Correa F., Schild A.L, Lemos R.A.A. \& Borges J.R.J. (Eds), Doenças de Ruminantes e Equídeos. Vol.1. 3rd ed. Pallotti, Santa Maria.

Ferreira S.F., Guimarães T.P., Moreira K.K.G., Alves V.A., Lemos B.J.M. \& Souza F.M. 2013. Caracterização fecal de bovinos. Revta Ciênc. Eletrôn. Med. Vet. 11:1-22.

Galyean M.L. \& Rivera J.D. 2003. Nutritionally related disorders affecting feedlot cattle. Can. Vet. J. 83(1):13-20. <https://dx.doi.org/10.4141/A02-061>

Grandin T. 2016. Evaluation of the welfare of cattle housed in outdoor feedlot pens. J. Am. Anim. Vet. Sci. 1-2(2):23-28. <https://dx.doi.org/10.1016/j. vas.2016.11.001>

Guizelini C.C., Lemos R.A.A., Paula J.L.P., Pupin R.C., Gomes D.C., Barros C.S.L., Neves D.A., Alcântara L.O.B., Silva R.O.S., Lobato F.C.F. \& Martins T.B. 2019. Type $\mathrm{C}$ botulism outbreak in feedlot cattle fed contaminated corn silage. Anaerobe 55:10-106. <https://dx.doi.org/10.1016/j.anaerobe.2018.11.003> $<$ PMid:30408576>

Hay K.E., Morton J.M., Mahony T.J., Clements A.C.A. \& Barnes T.S. 2016 Associations between animal characteristic and environmental risk factors and bovine respiratory disease in Australian feedlot cattle. Prev. Vet. Med 125:66-74. <https://dx.doi.org/10.1016/j.prevetmed.2016.01.013> $<$ PMid:26830058>

Hernández J., Benedito J.L., Abuelo A. \& Castillo C. 2014. Ruminal acidosis in feedlot: from aetiology to prevention. Sci. World. J. 2014:1-8. Available on <https://www.hindawi.com/journals/tswj/2014/702572/> Accessed on Mar. 25, 2015. <https://dx.doi.org/10.1155/2014/702572>

Hubbs P.D. 2010. The origins and consequences of the american feedlot system. Doctoral Dissertation, Baylor University, Waco, Texas. 118p.

Kelly A.P. \& Janzen E.D. 1986. A review of morbidity and mortality rates and disease occurrence in North American feedlot cattle. Can. Vet. J. 27(12):496500. <PMid:17422726> 
Le Maréchal C., Hulin O., Macé S., Chuzeville C., Rouxel S., Poëzevara T., Mazuet C., Pozet F., Martin L., Viry A., Rubbens C. \& Chemaly M. 2019. A case report of a botulism outbreak in beef cattle due to the contamination of wheat by a roaming cat carcass: from the suspicion to the management of the outbreak. Animals 9(12):1025. <https://dx.doi.org/10.3390/ani9121025> $<$ PMid:31775272>

Maboni F., Monego F., Dutra I., Costa M.M.D. \& Vargas A.C.D. 2010. Ocorrência de botulismo em bovinos confinados no Rio Grande do Sul. Ciênc. Anim. Bras. 11(4):962-965. <https://dx.doi.org/10.5216/cab.v11i4.3336>

Malafaia P., Granato T.L., Costa R.M., Souza V.C.D., Costa D.F.A. \& Tokarnia C.H. 2016. Major health problems and their economic impact on beef cattle under two different feedlot systems in Brazil. Pesq. Vet. Bras. 36(9):837843. <https://dx.doi.org/10.1590/s0100-736x2016000900008>

Martins R.A. 2016. Estudo da morbidade e mortalidade em confinamentos de bovinos para terminação e seus impactos econômicos. Master's Thesis in Animal Science, Escola de Veterinária, Universidade Federal de Minas Gerais, Uberlândia, MG. 91p.

Mayberry D., Bartlett H., Moss J., Davison T. \& Herrero M. 2019. Pathways to carbon-neutrality for the Australian red meat sector. Agricult. Syst. 175:13-21. <https://dx.doi.org/10.1016/j.agsy.2019.05.009>

Meyer N.F. \& Bryant T.C. 2017. Diagnosis and management of rumen acidosis and bloat in feedlots. Vet. Clin. N. Am., Food Anim. Pract. 33(3):481-498. <https://dx.doi.org/10.1016/j.cvfa.2017.06.005> <PMid:28823879>

Moreno L. \& Lanusse C. 2017. Specific veterinary drug residues of concern in meat production, p.581-603. In: Purslow P.P. (Ed.), New Aspects of Meat Quality. Woodhead, Duxford.

Mota R.G. \& Marçal W.S. 2019. Comportamento e bem-estar animal de bovinos confinados: alternativas para uma produção eficiente, rentável e de qualidade: revisão bibliográfica. Revta Bras. Hig. Sanid. Anim. 13(1):125141. <https://dx.doi.org/10.5935/1981-2965.20190010>

Nagaraja T.G. \& Lechtenberg K.F. 2007. Acidosis in feedlot cattle. Vet. Clin. N. Am., Food. Anim. Pract. 23(2):333-350. <https://dx.doi.org/10.1016/j. cvfa.2007.04.002><PMid:17606155>

Nickell J.S. \& White B.J. 2010. Metaphylactic antimicrobial therapy for bovine respiratory disease in stocker and feedlot cattle. Vet. Clin. N. Am., Food. Anim. Pract. 26(2):285-301. <https://dx.doi.org/10.1016/j.cvfa.2010.04.006> $<$ PMid:20619185>

Owens F.N., Secrist D.S., Hill W.J. \& Gill D.R. 1998. Acidosis in cattle: a review. J. Anim. Sci. 76(1):275-286. <https://dx.doi.org/10.2527/1998.761275x>

Pritchard R.H. 1993. Bunk Management. Proceedings Land O'Lakes Beef Seminar, Delivering the Difference Conference, Minnesota, p.4-15.

Rezende M.L.G. 2010. Avaliação de parâmetros clínicos, hematológicos e viabilidade econômica do uso de florfenicol na metafilaxia das afecções respiratórias inespecíficas de bovinos confinados no estado de Goiás. Master's Thesis in Animal Science, Escola de Veterinária, Universidade Federal de Goiás, Goiás. 45p.

Richeson J.T., Beck P.A., Gadberry M.S., Gunter S.A., Hess T.W., Hubbell III D.S. \& Jones C. 2008. Effects of on-arrival versus delayed modified live virus vaccination on health, performance, and serum infectious bovine rhinotracheitis titers of newly received beef calves. J. Anim. Sci. 86(4):9991005. <https://dx.doi.org/10.2527/jas.2007-0593><PMid:18192559>

Sanderson M.W., Dargatz D.A. \& Wagner B.A. 2008. Risk factors for initial respiratory disease in United States' feedlots based on producer-collected daily morbidity counts. Can. Vet. J. 49(4):373-378. <PMid:18481546>

Schwartzkopf-Genswein K.S., Beauchemin K.A., Gibb D.J., Crews Jr D.H., Hickman D.D., Streeter M. \& McAllister T.A. 2003. Effect of bunk management on feeding behavior, ruminal acidosis and performance of feedlot cattle: a review. J. Anim. Sci. 81(14):149-158. <https://dx.doi. org/10.2527/2003.8114_suppl_2E149X>

Silva S.S., Marmitt I.V.P., Felix S.R., Cassol D.M.S., Rezende M.L.G., Silva É.F., Meireles M.C.A. \& Nizoli L.Q. 2015. Assessing different chemoprophylactic protocols against bovine tickborne diseases and their influence on the weight gain of calves. Semina, Ciênc. Agrárias 36(4):2611-2617.<https:// dx.doi.org/10.5433/1679-0359.2015v36n4p2611>

Smith R.A. 1998. Impact of disease on feedlot performance: a review. J. Anim. Sci. 76(1):272-274. <https://dx.doi.org/10.2527/1998.761272x > <PMid:9464908>

Snyder E. \& Credille B. 2017. Diagnosis and treatment of clinical rumen acidosis. Vet. Clin. N. Am., Food Anim. Pract. 33(3):451-461. <https://dx.doi.org/10.1016/j.cvfa.2017.06.003> <PMid:28743471>

Soares M.C., Gaspar A.O., Brumatti R.C., Gomes D.C., Neves D.A., Alcântara L.O., Leal P.V. \& Lemos R.A. 2018. Economic impact of an outbreak of botulism in a cattle feedlot. Pesq. Vet. Bras. 38(7):1365-1370. $<$ https://dx.doi.org/10.1590/1678-5150-PVB-5643>

Urban-Chmiel R. \& Grooms D.L. 2012 Prevention and control of bovine respiratory disease. J. Livest. Sci. 3:27-36.

USDA 2011. Feedlot. Part IV: health and health management on US feedlots, with a capacity of 1,000 of more head. National Animal Health Monitoring System, United State Department of Agriculture, Washington, DC, p.1-100.

USP-ESALQ 2019. Conheça a história do primeiro confinamento do Brasil. Divisão de Comunicação, Escola Superior de Agricultura "Luiz de Queiroz" (ESALQ), Universidade de São Paulo (USP), Piracicaba, SP. 3p.

Valente T.N.P., Sampaio C.B., Lima E.D.S., Deminicis B.B., Cezário A.S. \& Santos W.B.R.D. 2017. Aspects of acidosis in ruminants with a focus on nutrition: a review. J. Agricult. Sci. 9(3):90-97. <https://dx.doi.org/10.5539/jas. v9n3p90>

Vigne G.L.D., Neumann M., Santos L.C., Stadler Júnior E.S., Pontarolo G.B., Petkowicz K. \& Cristo F.B. 2019. Digestibilidade do amido e comportamento ingestivo de novilhos confinados sob efeito de doses de complexo enzimático em dietas de alta densidade energética. Arq. Bras. Med. Vet. Zootec. 71(3):1015-1026. <https://dx.doi.org/10.1590/1678-4162-10538>

Wilson B.K., Richards C.J., Step D.L. \& Krehbiel C.R. 2017. Beef species symposium: best management practices for newly weaned calves for improved health and well-being. J. Anim. Sci. 95(5):2170-2182.<https:// dx.doi.org/10.2527/jas.2016.1006> 